ZOOLOGIA 30 (5): 513-518, October, 2013

http://dx.doi.org/10.1590/S1984-46702013000500007

\title{
The taxonomic status of Myotis levis levis and Myotis levis dinellii (Mammalia: Chiroptera: Vespertilionidae)
}

\author{
João M. D. Miranda ${ }^{1,5}$, Itiberê P. Bernardi², Jonas Sponchiado ${ }^{3}$ \& Fernando C. Passos ${ }^{4}$ \\ ${ }^{1}$ Departamento de Biologia, Universidade Estadual do Centro-Oeste do Paraná. Rua Fagundes Varela de Sá 03, \\ 85040-080 Guarapuava, PR, Brazil. \\ 2 Programa de Pós-Graduação em Ecologia e Conservação, Setor de Ciências Biológicas, Universidade Federal do Paraná. \\ Caixa Postal 19031, 81531-990 Curitiba, PR, Brazil. \\ 3 Programa de Pós-Graduação em Biodiversidade Animal, Centro de Ciências Naturais e Exatas, Universidade Federal de \\ Santa Maria. Cidade Universitária, prédio 17, 97105-900 Santa Maria, RS, Brazil. \\ ${ }_{4}^{4}$ Departamento de Zoologia, Setor de Ciências Biológicas, Universidade Federal do Paraná. Caixa Postal 19020, \\ 81531-9080 Curitiba, PR, Brazil. \\ ${ }^{5}$ Corresponding author. E-mail: guaribajoao@yahoo.com.br
}

\begin{abstract}
Investigating the Myotis levis complex is important for understanding the taxonomic status of the two subspecies currently recognized in it: Myotis levis levis (I. Geoffroy, 1824) and M. levis dinellii Thomas, 1902. Both M. levis levis and M. levis dinellii have been recently observed in sympatry in Argentina. This finding suggests that these populations might in fact correspond to distinct species rather than subspecies, as they have traditionally been designated. By using a multivariate morphometric approach, we demonstrate that M. I. levis has secondary sexual dimorphism in several measurements, with females being larger than males; sexual dimorphism was not detected in M. levis dinellii. However, we found morphometric differences between the two taxa. These differences exceeded those documented for other Neotropical Myotis. Based on their sympatry, morphological, and morphometrical differences, we propose a change in the status of both subspecies to $M$. levis and M. dinellii.
\end{abstract}

KEY WORDS. Morphometric; multivariate analysis; Neotropical Myotis; southern South America.

Myotis Kaup, 1829 is the largest genus of Vespertilionidae (LaVal 1973, Simmons 2005). There are 17 species in the Neotropical region, five of which are polytypic, including the Myotis levis complex (Simmons 2005, Stadelmann et al. 2007, Gardner 2008, Moratelli \& Wilson 2011, Moratelli et al. 2011). Although Myotis levis levis (I. Geoffroy, 1824) and Myotis levis dinellii Thomas, 1902 were described as species, both have commonly been treated as subspecies (Miller \& Allen 1928, LaVal 1973, Simmons 2005, Gardner 2008). LAVAL (1973) proposed the designation of $M$. levis dinellii as a subspecies of $M$. levis due to their similarity and their allopatric distributions. However, because only a few specimens were available in collections until recently, questions existed regarding the taxonomic status of these two taxa, which were discriminated mostly based on coloration and size (LAVAL 1973, BARQUez et al. 1999). With improved field sampling, M. levis levis and M. levis dinellii began to be recognized as parapatric populations (ANDERSON 1997, BARQUEZ et al. 1999). Recently, both taxa have been observed in the same location in Argentina (BARQUEz 2006) and, since then, some authors have considered M. levis dinellii as a species (BARquez 2006, Passos et al. 2010, Barquez et al. 2011, PAglia et al. 2012), promoting more confusion on the specific differentiation and taxonomic sta- tus of these taxa (Wilson 2008, Stevens et al. 2010, Peracchi et al. 2012). In this study, we used multivariate approaches to assess the morphometric variation and taxonomic status of the Myotis levis complex.

\section{MATERIAL AND METHODS}

In order to assess variation in qualitative and quantitative characters among Myotis levis senso lato populations, 52 adult specimens (with closed epiphyses) were examined (Appendix 1). All specimens were preserved in $70 \%$ alcohol and their skulls were removed and cleaned. All measurements were made by the same person (JMDM). These specimens have been previously assigned to Myotis levis based on the following set of traits, listed as diagnostic by LAVAL (1973), BARQUez et al. (1999), López-GonzÁlez et al. (2001), Wilson (2008), and Miranda et al. (2011): 1) sagittal crest usually absent, but if present, poorly developed; 2 ) fringe of hairs on the border of the uropatagium; 3) uropatagium with pale border; and 4) dorsal hairs bicolored. The following diagnostic traits were considered in the sub-specific differentiation: 1) forearm longer than $38 \mathrm{~mm}$ in M. levis levis and shorter than $38 \mathrm{~mm}$ in M. levis 
dinellii; 2) greatest length of skull longer than $14.4 \mathrm{~mm}$ in $M$. levis levis and smaller than $14.25 \mathrm{~mm}$ in M. levis dinellii; 3) dorsal hair slightly bicolored, with dark brown bases and light brown tips in M. levis levis and dorsal hair bicolored and strongly contrasting in M. levis dinellii, with dark brown bases and yellow tips; and 4) ventral hairs with dark brown at the base and white tips with frosted appearance in M. levis levis and dark brown at the base with light brown tips in M. levis dinellii (BARquez et al. 1999, Wilson 2008, Miranda et al. 2011).

Twenty-two specimens were assigned to M. levis dinellii (12 Males, 10 Females) and 32 specimens were assigned to $M$. levis levis $(9 \mathrm{M}, 23 \mathrm{~F})$. For a final comparative analysis, samples of four additional Brazilian species of Myotis were included: 4 specimens of Myotis albescens (É. Geoffroy, 1806) (3M, 1F); 37 Myotis nigricans (Schinz, 1821) (16M, 21F); 14 Myotis riparius Handley, 1960 (3M, 11F); and 38 Myotis ruber (É. Geoffroy, 1806) $(25 \mathrm{M}, 13 \mathrm{~F})$. For the last analysis, characters associated with secondary sexual dimorphism were not considered (each species was considered as a unique group). All specimens are deposited in the following scientific collections and are listed in Appendix 1 (followed by their abbreviations in parentheses): the Coleção Científica de Mastozoologia do Departamento de Zoologia da Universidade Federal do Paraná (DZUP) and the Museu de Zoologia da Universidade de São Paulo (MZUSP).

Using a Mitutoyo ${ }^{\circledR}$ digital caliper with a precision of $0.01 \mathrm{~mm}, 15$ metric characters (four external and 11 craniodental metrics) were measured: total length (TL) - the longest body length, from the snout to the tip of the tail; tail length (TaL) the distance from the most posterior region of the pelvis to the tip of the tail; ear length (EL) - the distance from the lowermost portion of the ear aperture to the tip of the ear; forearm length (FA) - the longest length of the forearm, including the carpus; condylobasal length (CBL) - the distance from the most posterior region of the occipital condyle to the proximal region of the central incisors; interorbital breadth (IB) - the smallest distance between orbital constrictions; greatest skull length (GSL) - the distance between the most posterior region of the occiput to the proximal region of the central incisors; postorbital constriction (POC) - the smallest width of the post-orbital constriction; breadth of braincase (BBC) - the longest length of the cranium; maxillar toothrow length (C-M) - the length from the most posterior region of the last molar to the anterior face of the canine of the corresponding side; mastoidal breadth (MB) the longest breadth of the mastoidal processes; mandible toothrow length (c-m) - the length from the most posterior region of the last molar to the anterior face of the canine of the corresponding side (on the mandible); mandible length (ML) the distance from the anterior region of the anterior incisive to the condylar process of the corresponding side; breadth across canines (C-C) - the longest distance through the cingulum of the upper canines; and breadth across molars (M-M) - the longest distance through the vestibular edges of the upper molars. Missing values (4.6\%) were estimated by the Principal Compo- nent Method (Strauss et al. 2003). Measures were normalized by log-transforming the original morphometric dataset.

Secondary sexual dimorphism was evaluated for both taxa using a multivariate analysis of variance (MANOVA) with Wilks' lambda as the statistic test. The MANOVAs included all 15 morphometric traits. In instances in which MANOVAs showed significant differences between the sexes, univariate analysis of variance (ANOVA) of each of the characters was used to detect which traits differed statistically. Once dimorphism was detected in a subspecies, the subsequent analysis treated these taxa as two groups (males and females).

In order to compare morphometric traits among three groups (M. levis dinellii, M. levis levis females, and M. levis levis males), a Principal Component Analysis (PCA) was carried out. PCAs were based on the correlation matrix and were employed to assess patterns of morphometric variation. PCA was used to summarize the general trends of size and shape variation within all morphometric traits. In order to confirm that the differences between taxa were not random, we used the MANOVA test. When the MANOVA with Wilks' lambda showed significant differences among these taxa, we performed univariate analyses of variance (one-way ANOVAs) for each of the characters, to detect which traits differed statistically between subspecies.

In order to assess the magnitude of the differences between M. levis levis and M. levis dinellii compared with other Brazilian Myotis, four other Brazilian species were added to the morphometric analysis (M. albescens, M. nigricans, M. riparius, and M. ruber - see Appendix 1). A new PCA was carried out with all six groups. All the analyses were carried out using the software PAST ${ }^{\circledast}$ version 2.14 (HAMmER 2012), and for all statistical analyses, findings were considered significant if $\mathrm{p}<0.05$.

\section{RESULTS}

Myotis levis levis - MANOVAs indicated the presence of significant dimorphism $\left(\mathrm{F}_{15,16}=3.345, \mathrm{p}=0.0109\right)$ in $M$. levis levis. Variable-by-variable comparisons showed that the sexes differed significantly in five variables: TL, TaL, FA, CBL, and ML (Table I). The five variables were, on average, greater in females than in males. Therefore, in later analyses, M. levis levis was considered as being composed of two groups (males and females).

Myotis levis dinellii - MANOVAs indicated no dimorphism $\left(\mathrm{F}_{15,6}=3.355, \mathrm{p}=0.07166\right)$ in $\mathrm{M}$. levis dinellii. Therefore, in subsequent analyses, $M$. levis dinellii was evaluated as a single group.

The PCA revealed two morphometrically separate groups (M. levis levis $\mathrm{x}$ M. levis dinellii), as well as a partial separation between males and females of $M$. levis levis (Fig. 1). The first two PCs accounted for $84.73 \%$ of the overall variance. PC1 was positively influenced by all variables, reflecting the overall size of the specimens. PC2 was influenced mainly by EL, IB, and POC, mostly reflecting cranial and body shapes (Table II). PCA showed differences among the two taxa, mostly in PC1, 


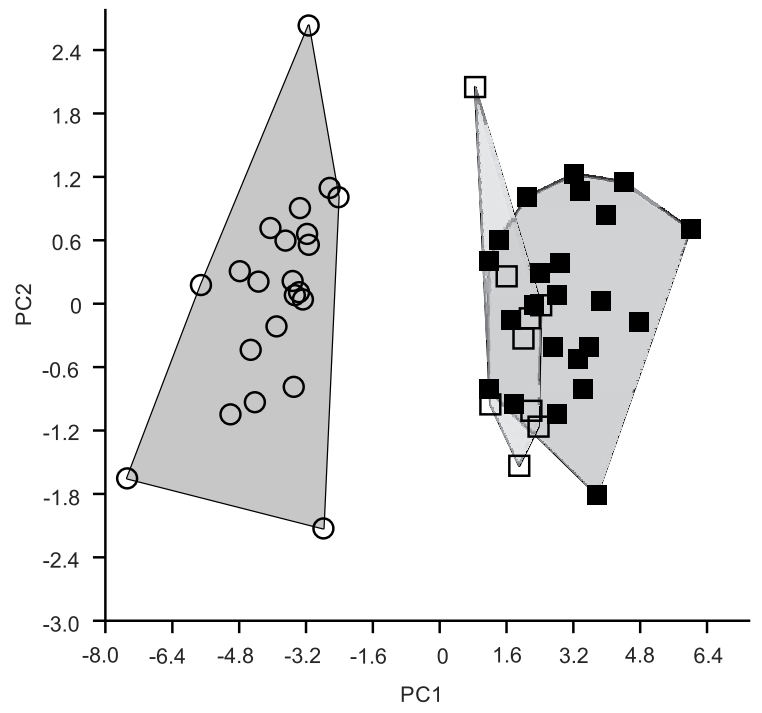

Figure 1. PCA scatter plot representing the projection of the three groups $(\square)$ Myotis levis levis males, $(\square)$ M. levis levis females and $(O)$ Myotis levis dinellii, in the multivariate space formed by PC1 and PC2.

i.e., size differences. The MANOVA tests confirmed the results of the PCA, indicating that both taxa were distinct according to their variables, and the sexes were distinct in M. levis levis (MANOVA, $\mathrm{F}_{30,76}=12.63, \mathrm{p}<0.0001$ ). All of the averages of these measures were significantly greater in $M$. levis levis than in M. levis dinellii (Table I).

Table I. One-way ANOVAs of 15 log-transformed morphometric traits of the Myotis levis levis and M. levis dinellii. Numbers in bold indicate significant differences.

\begin{tabular}{|c|c|c|c|c|}
\hline \multirow{2}{*}{ Variable } & \multicolumn{2}{|c|}{$\begin{array}{l}\text { M. levis levis males vs. } \\
\text { M. levis levis females }\end{array}$} & \multicolumn{2}{|c|}{$\begin{array}{l}\text { M. levis levis vs. } \\
\text { M. levis dinellii }\end{array}$} \\
\hline & $\mathrm{F}$ & $\mathrm{p}$ & $\mathrm{F}$ & $\mathrm{p}$ \\
\hline Total length & 24.8900 & $<0.00010$ & 90.08 & $<0.0001$ \\
\hline Tail length & 6.08200 & 0.019590 & 156.1 & $<0.0001$ \\
\hline Ear length & 1.50700 & 0.229200 & 96.29 & $<0.0001$ \\
\hline Forearm length & 4.48000 & 0.042700 & 252.3 & $<0.0001$ \\
\hline Condylobasal length & 6.89500 & 0.013480 & 195.9 & $<0.0001$ \\
\hline Interorbital breadth & 0.02960 & 0.864500 & 64.28 & $<0.0001$ \\
\hline Greatest skull length & 0.76240 & 0.389500 & 234.4 & $<0.0001$ \\
\hline Postorobital constriction & 2.74200 & 0.108200 & 14.93 & 0.00030 \\
\hline Breadth of braincase & 0.04386 & 0.835500 & 54.35 & $<0.0001$ \\
\hline Maxillar toothrow length & 2.20500 & 0.148000 & 315.8 & $<0.0001$ \\
\hline Mastoidal breadth & 1.24300 & 0.273700 & 161.8 & $<0.0001$ \\
\hline Mandibular toothrow length & 0.88780 & 0.353600 & 430.5 & $<0.0001$ \\
\hline Mandibular length & 9.49900 & 0.004379 & 179.3 & $<0.0001$ \\
\hline Breadth across canines & 1.53400 & 0.225100 & 122.1 & $<0.0001$ \\
\hline Breadth across molars & 3.35700 & 0.076850 & 240.0 & $<0.0001$ \\
\hline
\end{tabular}

Table II. Loadings of 15 log-transformed morphometric traits and principal components (PC1 and PC2) for Myotis levis levis (males and females) and Myotis levis dinellii.

\begin{tabular}{lcc}
\hline \multicolumn{1}{c}{ Variable } & PC1 & PC2 \\
\hline Total length & 0.89850 & 0.023660 \\
Tail length & 0.09753 & 0.097530 \\
Ear length & 0.71840 & -0.209500 \\
Forearm length & 0.94420 & -0.041540 \\
Condylobasal length & 0.96140 & -0.111600 \\
Interorbital breadth & 0.82800 & 0.261000 \\
Greatest skull length & 0.96270 & -0.038250 \\
Postorobital constriction & 0.53250 & 0.814700 \\
Breadth of braincase & 0.78610 & 0.171800 \\
Maxillar toothrow length & 0.94330 & -0.122900 \\
Mastoidal breadth & 0.93960 & -0.004275 \\
Mandibular toothrow length & 0.96220 & -0.140800 \\
Mandibular length & 0.95820 & -0.137700 \\
Breadth across canines & 0.89520 & -0.118300 \\
Breadth across molars & 0.93590 & -0.074520 \\
Percentage of variance (\%) & 78.7100 & 6.020000 \\
\hline
\end{tabular}

In order to compare the observed results with other Brazilian Myotis species, we carried out a new PCA using all measurements, this time including four additional species: $M$. albescens, $M$. nigricans, $M$. riparius, and $M$. ruber. The first three PCs summarized $86.26 \%$ of the overall variance. In this analysis, PC1 accounted for $72.1 \%$ of the variance in the dataset and was influenced by all variables equally, reflecting the size of the specimens. PC2 and PC3 accounted for $8.67 \%$ and 5.49\% of the variance in the dataset, respectively. PC2 was influenced most markedly by EL, POC, BBC, and C-C and PC3 was influenced most by TaL, IB, POC, and C-C, reflecting both cranial shape and body proportions (Table III). By making this comparison, we were able to characterize the considerable dissimilarity (in size) between M. levis levis and M. levis dinellii (Figs 2 and 3), with the magnitude of these differences being equal to or greater than those observed between formally accepted species of the same evolutionary group (Neotropical Myotis clade) (Simmons 2005, Stadelmann et al. 2007). The averages, standard deviations, sample sizes, and ranges of the measurements are provided in Table IV, to facilitate the comparison of M. levis levis and $M$. levis dinellii.

\section{DISCUSSION}

Recent records of $M$. levis levis in sympatry with $M$. levis dinellii in Argentina (BARQUEZ 2006, BARQUEZ et al. 2011) and in southern Brazil (PAssos et al. 2010) clearly indicate that both taxa are sympatric in part of their distributions. Therefore, the two taxa cannot be recognized as subspecies or geographical 

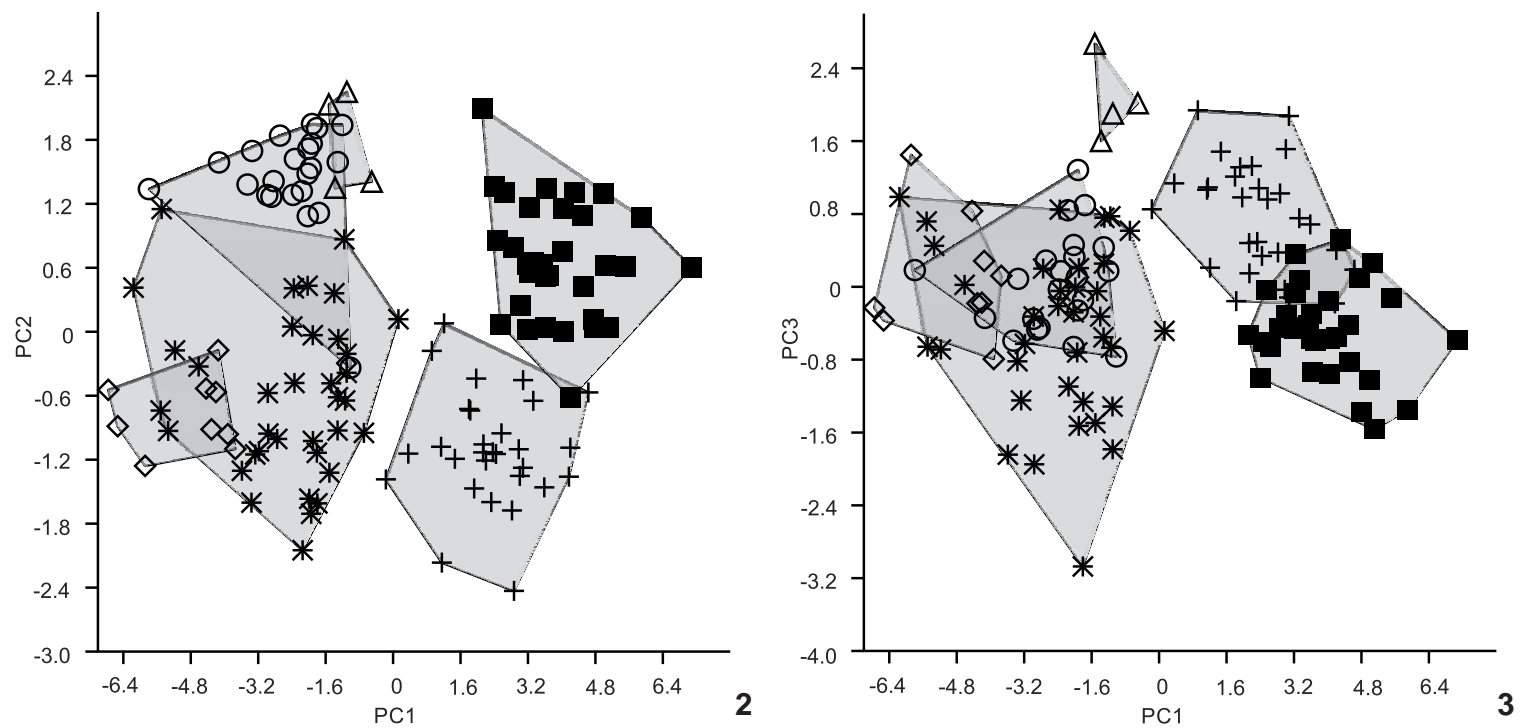

Figures 2-3. PCA scatter plot representing the projection of the six examined taxa $(\mathbf{\square})$ Myotis levis levis, $(\bigcirc)$ Myotis levis dinellii, $(+)$ Myotis ruber, $(*)$ Myotis nigricans, $(\diamond)$ Myotis riparius, and $(\boldsymbol{\Delta})$ Myotis albescens, in the multivariate space formed by PC1 and PC2 (2) and PC1 and PC3 (3).

Table III. Loadings of 15 log-transformed morphometric traits and principal components (PC1, PC2, and PC3) for Myotis levis levis and Myotis levis dinellii, Myotis albescens, Myotis ruber, Myotis riparius, and Myotis nigricans samples.

\begin{tabular}{lcrc}
\hline \multicolumn{1}{c}{ Variable } & PC1 & PC2 & PC3 \\
\hline Total length & 0.8210 & 0.28530 & -0.24710 \\
Tail length & 0.8083 & -0.07001 & -0.37190 \\
Ear length & 0.7158 & 0.33690 & -0.25460 \\
Forearm length & 0.9484 & -0.03826 & -0.09477 \\
Condylobasal length & 0.9675 & 0.09750 & -0.03321 \\
Interorbital breadth & 0.7045 & 0.05386 & 0.42230 \\
Greatest skull length & 0.9576 & -0.03178 & -0.09712 \\
Postorobital constriction & 0.6102 & 0.65080 & 0.36690 \\
Breadth of braincase & 0.7514 & 0.53620 & -0.04146 \\
Maxillar toothrow length & 0.9246 & -0.23680 & -0.08447 \\
Mastoidal breadth & 0.8875 & 0.10090 & 0.15000 \\
Mandibular toothrow length & 0.9391 & -0.24060 & -0.08357 \\
Mandibular length & 0.9414 & 0.24090 & 0.01408 \\
Breadth across canines & 0.7700 & -0.33320 & 0.42070 \\
Breadth across molars & 0.8869 & -0.28010 & 0.10910 \\
Percentage of variance (\%) & 72.100 & 8.67000 & 5.49000 \\
\hline
\end{tabular}

races of the same species (MAYr 1969, 1970, 1998), as traditionally accepted (Miller \& Allen 1928, LaVal 1973, Barquez et al. 1999, Bianconi \& Pedro 2007, Wilson 2008, Stevens et al. 2010, Peracchi et al. 2012).

The differences between M. levis levis and M. levis dinellii found in the present study revealed considerable divergence,
Table IV. External and cranial measurements of Myotis levis levis and Myotis levis dinellii. Averages \pm one standard deviation, followed by the sample size in parenthesis and the range within each population and species.

\begin{tabular}{lll}
\hline \multicolumn{1}{c}{ Variable } & \multicolumn{1}{c}{ M. levis levis } & \multicolumn{1}{c}{ M. levis dinellii } \\
\hline Total length & $92.94 \pm 4.80(\mathrm{n}=29)$ & $82.74 \pm 2.71(\mathrm{n}=21)$ \\
& $84.3-0102.20$ & $74.46-86.92$ \\
Tail length & $45.16 \pm 3.08(\mathrm{n}=30)$ & $36.53 \pm 2.13(\mathrm{n}=21)$ \\
& $40.05-52.00$ & $29.48-40.28$ \\
Ear length & $16.35 \pm 1.55(\mathrm{n}=30)$ & $13.71 \pm 0.62(\mathrm{n}=21)$ \\
& $12.45-20.45$ & $12.28-14.90$ \\
Forearm length & $40.82 \pm 1.43(\mathrm{n}=34)$ & $35.87 \pm 0.79(\mathrm{n}=22)$ \\
& $38.15-43.40$ & $34.25-37.25$ \\
Condylobasal length & $14.54 \pm 0.42(\mathrm{n}=33)$ & $13.05 \pm 0.31(\mathrm{n}=20)$ \\
& $13.85-15.40$ & $12.30-13.55$ \\
Interorbital breadth & $4.91 \pm 0.17(\mathrm{n}=32)$ & $4.46 \pm 0.18(\mathrm{n}=22)$ \\
& $4.65-5.25$ & $4.15-4.75$ \\
Greatest skull length & $15.39 \pm 0.44(\mathrm{n}=31)$ & $13.82 \pm 0.30(\mathrm{n}=21)$ \\
& $14.40-16.75$ & $13.00-14.25$ \\
Postorobital constriction & $3.91 \pm 0.11(\mathrm{n}=34)$ & $3.81 \pm 0.10(\mathrm{n}=22)$ \\
& $3.70-4.10$ & $3.61-4.06$ \\
Breadth of braincase & $7.38 \pm 0.19(\mathrm{n}=32)$ & $7.02 \pm 0.16(\mathrm{n}=21)$ \\
& $7.00-7.75$ & $6.70-7.36$ \\
Maxillar toothrow length & $5.98 \pm 0.20(\mathrm{n}=34)$ & $5.18 \pm 0.14(\mathrm{n}=22)$ \\
& $5.65-6.80$ & $4.90-5.65$ \\
Mastoidal breadth & $7.76 \pm 0.15(\mathrm{n}=32)$ & $7.27 \pm 0.13(\mathrm{n}=22)$ \\
Mandibular toothrow & $7.45-8.05$ & $6.98-7.47$ \\
length & $6.24 \pm 0.17(\mathrm{n}=33)$ & $5.40 \pm 0.15(\mathrm{n}=22)$ \\
Mandibular length & $5.90-6.60$ & $5.13-5.90$ \\
& $11.22 \pm 0.47(\mathrm{n}=33)$ & $9.84 \pm 0.25(\mathrm{n}=22)$ \\
Breadth across canines & $9.80-12.15$ & $9.23-10.30$ \\
& $3.82 \pm 0.14(\mathrm{n}=31)$ & $3.49 \pm 0.09(\mathrm{n}=22)$ \\
Breadth across molars & $3.40-4.05$ & $3.29-3.64$ \\
& $6.04 \pm 0.12(\mathrm{n}=33)$ & $5.39 \pm 0.19(\mathrm{n}=22)$ \\
\hline & $5.75-6.25$ & $5.05-5.90$ \\
\hline & &
\end{tabular}


mostly in size. These differences indicate that distinct evolutionary pressures have affected their evolution. Size may be a line of least evolutionary resistance, driving the evolutionary direction (Marroig \& Cheverud 2005). In fact, size tends to account for most of the interspecific variation within the genus (see the main steps in the key of identifications of species, e.g., BARQUEZ et al. 1999, GARDNER 2008). Variation in body size among bat species changes the echolocation frequencies and breadth of feeding niches (Simmons \& Conway 2003). The PCAs indicated that the main difference was in size (PC1), whereas the MANOVAs clearly separated both taxa. LAVAL (1973) had already pointed out the size difference between the two taxa, yet underscored the great morphological similarity between them. Our approach, based on multivariate morphometrics, indicated that M. levis levis and M. levis dinellii are distinct. This finding led us to the following more conceptual questions: 1 ) What is the magnitude of the differences between M. levis levis and $M$. levis dinellii? 2) How many of these differences reflect taxonomic differences when compared with other species of the evolutionary group of Neotropical Myotis? 3) To what taxonomic hierarchical level should these two taxa be assigned?

The last PCA of M. levis levis, M. levis dinellii, M. albescens, M. nigricans, M. riparius, and M. ruber showed that the morphometric differences between M. levis levis and M. levis dinellii were as great as or greater than those observed among the other species analyzed. Myotis levis levis was more similar in size to M. ruber than to M. levis dinellii, and the latter, in turn, was more similar in size to M. albescens and M. nigricans than to $M$. levis levis. Myotis levis levis was clearly distinct from M. ruber in the color of the fur. Myotis levis dinellii was clearly distinct from $M$. nigricans in fur color and in the presence of a fringe of hair in the border of the uropatagium, and from M. albescens in the color of the fur and a had a smaller POC (BARQuez et al. 1999, WiLSON 2008, Miranda et al. 2011).

Further, secondary sexual dimorphism was observed in specimens of M. levis levis, but not in M. levis dinellii. Females were larger than males in $M$. levis levis. These findings are similar to the sexual dimorphism observed in M. nigricans (MORATELLI et al. 2011) and in other vespertilionid bats (MYers 1978), possibly a response to selective pressures relating to gestation, maternal care, and flight.

Therefore, our combined evidence supports the existence of two distinct taxa, given that they are: 1) sympatric; 2) morphologically distinct (in fur coloration); 3) morphometrically different; and 4) morphometrically different from one another to an extent that is similar to or greater than the differences among other species in their evolutionary group. Therefore, we agree with BARQuez (2006), PAssos et al. (2010), BARQuez et al. (2011), and Paglia et al. (2012) and consider M. levis and M. dinellii to be separate species.

Despite new molecular data, uncertainties regarding Myotis evolutionary relationships still exist (RUEDI \& MAYER 2001, STADELmann et al. 2007). Increasing field efforts and also other types of analysis such as tooth morphology and molecular data, which we consider better tools than the purely morphometric analysis in the present study, will allow a more comprehensive understanding of the evolutionary relationships relating to the diversification of this cosmopolitan genus.

\section{ACKNOWLEDGMENTS}

We thank CNPq for the productivity scholarship granted to FCP (303757/2012-4), and REUNI-UFPR and CAPES for the scholarships of IPB and JS. We thank Mário de Vivo for access to specimens from MZUSP. We also thank Marcio R. Pie, James J. Roper, and Diego Astúa de Moraes who provided useful comments and suggestions on the manuscript and the English version of it.

\section{LITERATURE CITED}

ANDERSON, S. 1997. Mammals of Bolivia, taxonomy and distribution. Bulletin of the American Museum of Natural History 231: 1-652.

Barquez, R.M. 2006. Orden Chiroptera, p. 56-86. In: R.M. Barquez; M. Díaz \& R.A. OJeda (Eds). Mamíferos de Argentina, Sistemática y Distribución. Tucumán, SAREM, 359p.

Barquez, R.M.; M.A. Mares \& J.K. Braun. 1999. The Bats of Argentina. Special Publications. Museum of Texas Tech University 42: 1-275.

Barquez, R.M.; M.S. SÁnchez \& M.L. SANdoval. 2011. Nuevos registros de murciélagos (Chiroptera) en el norte de Argentina. Mastozoologia Neotropical 18 (1): 11-24.

Bianconi, G.V. \& W.A. Pedro. 2007. Família Vespertilionidae, p. 167-195. In: N.R. Reis; A.L. Peracchi; W.A. Pedro \& I.P. Lima (Eds). Morcegos do Brasil. Londrina, Nélio R. dos Reis, 253p.

Gardner, A.L. 2008. Mammals of South America: volume 1: marsupials, xenarthrans, shrews and bats. Chicago, The University of Chicago Press, 669p.

Hammer, Ø. 2012. PAST. Paleontological statistic. Version 2.14. Reference manual. Oslo, Natural History Museum, University of Oslo, 225p.

LAVAL, R. 1973. A revision of the Neotropical bats of the genus Myotis. Natural History Museum Los Angeles County 15: 1-54.

López-González, C.; S.J. Presley; R.D. Owen \& M.R. Willig. 2001. The taxonomic status of Myotis (Chiroptera: Vespertilionidae) in Paraguay. Journal of Mammalogy 82: 138-160.

Marroig, G. \& J.M. Cheverud. 2005. Size as a line of least evolutionary resistance: diet and adaptative morphological radiation in New World Monkeys. Evolution 59: 1128-1142.

MaYr, E. 1969. Principles of systematic zoology. New York, McGraw-Hill, 434p.

MAYr, E. 1970. Populations, species and evolution. Cambridge, Harvard University Press, 453p.

MAYR, E. 1998. O desenvolvimento do pensamento biológico: diversidade, evolução e herança. Brasília, Editora Universidade de Brasília, 1107p. 
Miller, G.S. \& G.M. Allen. 1928. The American bats of the genera Myotis and Pizonyx. United States National Museum Bulletin 144: 1-218.

Miranda, J.M.D.; I.P. Bernardi \& F.C. PAssos. 2011. Chave ilustrada para a determinação dos morcegos da Região Sul do Brasil. Curitiba, João M.D. Miranda, 51p.

Moratelli, R. \& D.E. Wilson. 2011. A new species of Myotis Kaup, 1829 (Chiroptera, Vespertilionidae) from Ecuador. Mammalian Biology 76: 608-614.

Moratelli, R.; A.L. Peracchi; D. Dias \& J.A. Oliveira. 2011. Geographic variation in South American populations of Myotis nigricans (Schinz, 1821) (Chiroptera, Vespertilionidae), with the description of two new species. Mammalian Biology 76: 592-607.

Myers, P. 1978. Sexual dimorphism in size of vespertilionid bats. American Naturalist 112 (986): 701-711.

Paglia, A.P.; G.A.B. Fonseca; A.B. Rylands; G. Herrmann; L.M.S. Aguiar; A.G. Chiarello; Y.L.R. Leite; L.P. Costa; S. Siciliano; M.C. Kierulff; S.L. Mendes; V.C. Tavares; R.A. Mittermeier \& J.L. Patton. 2012. Annotated checklist of Brazilian Mammals, 2nd Edition. Occasional Papers in Conservation Biology 6: 1-82.

Passos, F.C.; J.M.D. Miranda; I.P. Bernardi; N.Y. Kaku-Oliveira \& L.C. Munster. 2010. Morcegos da Região Sul do Brasil: análise comparativa da riqueza de espécies, novos registros e atualizações nomenclaturais (Mammalia, Chiroptera). Iheringia 100 (1): 25-34.

Peracchi, A.L.; I.P. Lima; N.R. Reis; M.R. Nogueira \& H. OrtêncioFilho. 2012. Ordem Chiroptera, p. 155-234. In: N.R. ReIs; A.L. Peracchi; W.A. Pedro \& I.P. Lima (Eds). Mamíferos do
Brasil. Londrina, Nélio Roberto dos Reis, $2^{\text {nd }}$ ed., 439p.

Ruedi, M. \& F. Mayer. 2001. Molecular systematics of bats of the genus Myotis (Vespertilionidae) suggests deterministic ecomorphological convergences. Molecular Phylogenetics and Evolution 21: 436-448.

Simmons, N.B. 2005. Order Chiroptera, p. 312-529. In: D.E. Wilson \& D.M. Reeder (Eds). Mammal species of the world: a taxonomic and geographic reference. Baltimore, Johns Hopkins University Press, vol. 1, 2142p.

Simmons, N.B. \& T.M. Conway. 2003. Evolution of ecological diversity in bats, p. 493-535. In: T.H. Kunz \& M.B. FEnTON (Eds). Bat ecology. Chicago, University of Chicago Press, 798p.

Stadelmann, B.; L.K. Lin; T.H. Kunz \& M. Ruedi. 2007. Molecular phylogeny of New World Myotis (Chiroptera, Vespertilionidae) inferred from mitochondrial and nuclear DNA genes. Molecular Phylogenetics and Evolution 43: 32-48.

Stevens, R.D.; C. López-González; E.S. McCulloch; F. Netto \& M.L. ORTIz. 2010. Myotis levis (Geoffroy Saint-Hilaire) indeed occurs in Paraguay. Mastozoologia Neotropical 17 (1): 195-200.

Strauss, R.E.; M.N. Atanassov \& J.A. Oliveira. 2003. Evaluation of the Principal-Component and Expectation-Maximization methods for estimating missing data in morphometric studies. Journal of Vertebrate Paleontology 23: 284-296.

WiLSON, D.E. 2008. Genus Myotis Kaup 1829, p. 468-481. In: A.L. GARDNER (Ed.). Mammals of South America: marsupials, xenarthrans, shrews and bats. Chicago, The University of Chicago Press, vol. 1, 669p.

Appendix 1. Specimens examined, museums and acronyms: mammalogy collections of the Universidade Federal do Paraná (DZUP), Zoology Museum of the Universidade de São Paulo (MZUSP), and Mammal Collection at Universidade Federal Rural do Rio de Janeiro (ALP).

Myotis albescens: BraziL, Rio Grande do Sul: Frederico Westphalen Municipality (DZUP 574, 575, 576); Paraná: Porto Rico, Mutum Island (DZUP 226).

Myotis levis dinellii: BraziL, Rio Grande do Sul: Derrubadas, Parque Estadual do Turvo (8) (DZUP 701, 703, 704, 705, 706, 707, 708, 709, 710, 711); Santa Catarina: Ponte Alta do Norte (7) (DZUP 867-877); Argentina: Tucumán: Las Vasquez Municipality (9) (MZUSP 2055).

Myotis levis levis: BrazIL, Rio de Janeiro: Nova Friburgo (1) (MZUSP 2799); São Paulo: Cananéia, Parque Estadual Ilha do Cardoso (2) (MZUSP 27680, 27976); Paraná: Curitiba, Parque Municipal da Barreirinha (3) (DZUP 333, 334, 335, 336); Palmas (4) (DZUP 216, 217, 218, 369, 371, 372, 373, 376, 377, 380, 381, 382, 384, 385, 386, 387, 388, 389, 391, 392, 393, 394, 395, 396); Rio Grande do Sul: Cacequi (5) (MZUSP 3167).

Myotis nigricans: BrazIL, Paraná: Cerro Azul, State Park of Campinhos (DZUP 056, 057,058, 059, 061, 062, 063, 064, 065, 066, 086, 087, 088, 090, 092, 093, 096, 097, 099, 105, 106, 107, 108, 109, 110, 111, 112); Matinhos, State Park of Rio da Onça (DZUP 141, 144); São José dos Pinhais (DZUP 235, 236); Balsa Nova, São Luiz do Purunã locality (DZUP 410, 419, 420, 421, 422).

Myotis riparius: BrazIL, São Paulo: Juquitiba (MZUSP 32966); Piedade (MZUSP 32963, 32964); Paraná: Maringá (DZUP 494, 495, 499, 500); Rio Grande do Sul: Frederico Westphalen (DZUP 577, 578).

Myotis ruber: Brazil, São Paulo: Buri (MZUSP 32968, 32971, 32972, 32974, 32975); São Paulo, State Park of Serra da Cantareira (MZUSP 31466, 31470, 31471, 31472, 31473); Paraná: Balsa Nova, Bugre (DZUP 191, 192, 193, 194, 206, 337); São Luiz do Purunã (DZUP 231, 232, 474, 475, 476, 477); Palmas (DZUP 213, 214); Santa Catarina: Passos Maia (DZUP 397, 478, 498); Urussanga (DZUP 580); Rio Grande do Sul: Frederico Westphalen (DZUP 582).

Submitted: 10.XII.2012; Accepted: 25.III.2013.

Editorial responsibility: Diego Astúa de Moraes

ZOOLOGIA 30 (5): 513-518, October, 2013 